\title{
Ethical Issues of Local Government and Human Government
}

\author{
Syarief Makhya \\ Faculty of Social and Political Sciences, \\ University of Lampung \\ Lampung - Indonesia \\ symakhya@yahoo.com
}

\begin{abstract}
In the era of Post-New Order government, the government has made strategic policies to build a democratic system of government and clean government. The policy is carried out by realizing political democratization, decentralization of government, bureaucratic reformation, and law enforcement. But the trend had not been effective in building a clean government and public trust. The purpose of this study was to describe the ethical problems of government and this study uses the secondary data research method in which the researcher used secondary data (desk research method). The results of this study show that in governance, ethical governance practically used as a reference and backrest to build and run the government based on values. The governance in the area is still oriented to meet formal standards, the distribution of financial resources which are not oriented to meet the public interest, as well as the abuse of power. Finally, the absence of ethical awareness may be caused by lack of idealism and governing and the characters of government officers who are still driven by formal rules.
\end{abstract}

Keywords - Ethics, Governance, Values

\section{INTRODUCTION}

In the era of Post-New Order government, the public has great expectations on the execution of the regional government, at least the expectation is to give an answer to a question that has been problematic in the New Order era namely, the practice of authoritarianism, corrupted governments, and public services that are loaded with extortion, illegal public services, and bureaucratic oriented practices.

Therefore, the issue of democratization, good governance, and quality public services, are of the main issues to be used as an agenda of reformed era in addressing the legacy of the New Order regime. The government then realizes them into several types namely, regional governmental democracy, reformation of governmental bureaucracy, and the implementation of regional autonomy.

In the period of more than 15 years, there has been a significant change in the area. Regional government in the New Order era are only placed as implementers of government policy and became the center of the sub-ordinate central government, into areas that actually carry out extensive regional autonomy, democratic political life, and renewal in the public service sector various.

However, the efforts and perspectives to reform the postNew Order government are limitedly implemented in disourse level wwithout touching how a value can be built in the system of government. As a result, the government post New Order government has not been able to realize a clean government, can be controlled effective and trusted by the people.

Therefore, this paper discusses the issues why the government has not succeeded in realizing the regional government has not succeed in implementing clean government and public trust?

\section{METHOD}

This study uses the secondary data research method in which the researcher used secondary data (desk research method). The data were obtained from the internet and print media. The data were, then, analyzed using relevant theory concerning the concept of ethical governance and public policy.

\section{DISCUSSION}

\section{A. The problems of Governmental Ethics}

In the last 15 years of post New Order government, there have been emerging policies in local government that cause controversyies resulting in considerable public criticism, one 
of which is related to the use local governmental expenditure allocations (Makhya, 2012).

There are several ways to perform wasteful budget, i.e. official travel, luxurious official car purchases, overseas visits, renovation of office space, parking facilities manufacture of office, comparative study, etc. Although there are many critics and public condemnation, these paractices are still prevalent. One reason that is always used to justify the practices is that the policies do not contradict with the policies. The goverment justifies that the practices are valid and comply with the current rules.

In practice this current government that is always used in making a decision, there are two bases that are used to make decidion making, first is logica normative approach that emphasizes the activities that are conducted under the procedures and laws and regulations (rules driven). On the basis of such logical approach, in budget planning, policy makers (government and legislative institutions) can allocate the amount fund according to his interests to the extent that it does not violate existing regulations. For example, the government might allocate the budget for expenditure of official vehicles at a great price and luxurious every year as long as it was not contrary to the prevailing legal regulations, although the condition of the vehicle that is still considered feasible. Other example is that member of the Board may allocate a budget for comparative studies or renovate office space in a large amount of funds to the extent they do not conflict with existing law.

As a consequence, the logica of rules driven approach in the distribution of the budget, the budget allocation might be disproportionate, inefficient, and priority choice is marginalized. Furthermore, it is not only unfair, unequal but also neglecting the the poor. The distribution of the budget tend to be only as a bargaining chip between government and legislative institutions to accommodate a variety of interests and practice of rent seeking (Makhya, 2012).

The government's ways of executing the program that solely based on formal legal principle is merely way of avoiding legal entrapment so that they can be free from the problem of corruption and abuse of authority. These practices will give rooms for policy makers to utilize the budget as a political and economic resources for personal and group interests. In this perspective, the budget process is made untransparent and and unparticipative because it can avoid any public control.

In the process of budget planning, formal legal application is actually only one of the the principles the government can adopt. There are a number of principles in the budget process that can be applied such as: the principle of efficiency and effectiveness principle, transparency prinicple, budgeting simplicity principle, equality budgeting principle, etc. In each budget planning, home minister and financial minister provides guidelines for preparing budgets in which it includes a number of those principles and development priorities.

However, in practical level, the governemnt only use formal legal principles as a reference that tends to ignore other principles. Whereas other the principles such as transparency, participatory, and accountability in budgeting planning lies only in the level of formality. For example, public participation in planning forums, for example, as one of the stages that must be done in the process of public budgeting tends to be interpreted as a forum for disseminating the program - a government program, because there is no debate and no dialogue process to formulate policy issues and development priorities properly and in accordance with the reality of the public perceived problems public.

Therefore, the basic problem of budgeting is inefficiency, and it does not solve with problems faced by the community. This practice tends to be used to maximize the economic benefits for public officials, among other things because of the policy-making process cannot be controlled effectively.

In the process of budget planning, the legislative members who are expected to serve as a control function, turn out to involve budget allocation, and they propose program and prioritize the interests of the aspirations of their constituencies. In other words, the relations between the legislative members and the government is compromistic in nature to protect and guard their own interests. While the power of civil society, executed especially by NGO activists, academics and mass media, regardless of how hard the protest against the budgeting plan will never win the results and they cannot change the policies.

Therefore, the practice of good governance that is only driven by merely formal rules cannot be controlled effectively. It follows that that public budget can be manipulated by public officials for the sake of seeking economical benefits.

\section{B. Humane Government}

The governance process driven by the formal rules does not violate the rule of law. However, having such cases like budget inefficiency, budget manipulating, budget planning focused only on administrative and financial order, fictitious budget planning are categorized and violation of governmental ethic. Other cases like corruption, bribery, embezzlement, graft and mafia cases in the judicial and tax mafia happened recently in Indonesia are also contrary to the ethics and morality.

Cases related to ethics in the civil service as mentioned above involve some professions that violated state ethics as 
administration officials, legislators, prosecutors, judges, police, taxation of employees, and so forth.

In the context of governance implementation, ethical mater in government bureaucracy is very important so that the government bureaucracy continues to earn the trust from society and and can also realizea clean governmental implemetation. Proffession ethics or bureaucracy ethics refer to ethics pertaining to the duties carried out by someone demonstratested with the duties and certain responsibilities that require time and attention which is carried by the holder of the office (Simorangkir: 1978).

Thus bureaucracy ethics is a good habit in the bureaucracy which then internalized into norms or rules. In other words, it becomes normative in human life and state administration. However, in the tradition of government in Indonesia, moral values in goverment is not used as a reference as a form guidance of behavior and the basis for the government officers and policymakers in making decisions and public policy.

Government's ways of working that are still dominated based on the concept of Max Weber is one reason why the governmental practices neglect of the values dimension. According to Weber (Noor, 2012), bureaucracy is the best method of organization by specialization of the tasks. According to Weber, thera are several basic principles and characteristics of bureaucracy; (a) specialization; (b) hierarchy; (c) abstract code; (d) impersonal; (e) competency, carreer and promotion; (e) discipline

Weber's ideal principle put forward pays no attention to human aspects in the bureaucracy. Meanwhile the effectiveness and efficiency of the bureaucracy are very much influenced by the ethics and morality of employees.

Governmental execution is essentially directed to serve the public interest. Therefore, the government serves a role as a public servant. As a consequence, government is mandated as a public servant. Therefore, the government should have a humanistic orientation by which it prioritizes humanitarian values.

Based on humane governmental model, a person is better valued in terms of his/her usefulness. The nature of human is not just maximized in their benefits or human being merely serve their role as machines goals. Therefore, the values of well-being, dignity and freedom must be inherent in the governance process (Muhtar, 2008). The basic principle in the government, namely the humane orientation and the achievement of government objectives should be devoted to the provision of public services as depicted in the concept of Hegalian bureaucracy

Changing tradition of Weberian bureaucracy to bureaucracy Hegalian is not easy because Indonesian bureaucratic positions not in the neutral. There is still strong influence of the intervention of political forces against the policy making process. Instead of being a public servant, the position of bureucrats is loyalists of regional heads. As a result, their orders and instructions should be absolutely obeyed by the subordinates their subordinates although the substance is not in the public interest.

Corruption, collusion, nepotism, graft, and abuse of authority in the practice of governance are of prevalent phenomenon because the governmental bureaucracy is exploited for the solely the benefit of maximizing economic benefits to government officials. Available resources such as the regional budget, local assets, and financial resources of the area are massively exploited by government officials for the take of economic benefits.

The impact of this practice is that there is dehumanization process. It follows that Regional Expenditure and Remuneration Budget and other regional financial resources (taxes, levies), and the orientation of the policy that should be intended to improve the welfare of the people is slowly manifested.

A humane government model can only be realized if the government administration has ethical or moral accountability to the public. There are several forms of ethical and moral accountability such as resigning fromcertain position when governmental officersfail to perform their best efforts, strict sanctions to goverment officers who violate the ethical position, evaluation of performance is conducted objectively and it should be done regularly so that work achievement and task performed by government officers can be measured. Public criticism and public resistance toward government policy should be used as benchmarks to judge the performance of government.

In addition to the aformementioned above, there must be condition that encourage government officers posses integrity, simplicity and the officers put positions as a way to serve the community not abusing for moral hazard and corrupting country's wealth for individual intererst. This can be manifetsed by making the standards abound to regulate the needs of officers reasonably but not excessively, such as the purchase of official vehicles for officers and other facilities.

Ethical Accountability and standardized behavior of governmental officers have not been put into practice as culture of good governenance. Consequently, the formation of bureucrstic government that was done in Indonesia do not touch on the dimensions of cosntructing value system. The bureucratic reformation is till limited on formal structure of government.

In the paradigm of New Public Service (NPS), it is necessaary to have ethical awareeness. The a citizen (the 
citizen) should obtain the perfect services from the government. Therefore, the government should not only control (steering) and satisfies their customers or constituents, but rather they have to serve the whole society. Awareness of giving the best service to the citizens is the manifestation of ethical awareness in realizing humane government.

\section{CONCLUSION}

Governmental bureaucracy refiormation that emphasizes only on the improvement of the formal governance structure and capacity building of government does not give guarantee of a government free of corruption (Corruption, Collusion and Nepotism). In reality the pretext of hiding behind the formal rules, ethical violationsoften occurs in varieties of forms namely, governmental administration resources such as finance, assets and authorities are used as a tool to maximize and to take personal benefits.

There is no ethical accountability and standards of behavior that result in the official governance process that are not based on the values and morals. Therefore, ethical awareness among the government officers and governmental personnel is necessary by which the government can give the best service to the citizen.

\section{REFERENCES}

Makhya, Syarief. Berlindung di Balik Aturan Formal, Media Indonesia, 2012

Makhya, Syarief. The Formulation of Lampung Provincial Budget Policy of 2011.

International Conference of Decentralization 2012, IPDN Indonesia, 21 November 2012.

Muhtar, Entang Adhy. 2008. Birokrasi Humanistik: Pelayanan Publik Berdasar Entrepreneurship Dalam Perspektif Kultural dan Etika, dalam Governance, Volume 4, Nomor 15, Juli-September 2008, Halaman 2445

Noor, Irwan, 2012. Birokrasi Weber dalam Kajian Administrasi Publik. http://irwannoor.lecture.ub.ac.id/2012/05/birokrasi-weber/ diakses 2 Oktober 2016

Simorangkir, OP. 1978. Etika Jabatan. Aksara Persada Indonesia : Jakarta. 